International Journal of Instruction e-ISSN: 1308-1470 • www.e-iji.net

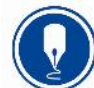

January $2022 \bullet$ Vol.15, No.1

p-ISSN: 1694-609X

pp. 583-600

Article submission code:

20210114125253
Received: 14/01/2021

Revision: 16/07/2021
Accepted: 11/08/2021

OnlineFirst: 08/11/2021

\title{
Metacognitive Reading Strategies of English Lesson at Indonesian Civil Aviation Polytechnic
}

\section{Laila Rochmawati}

Dr., Politeknik Penerbangan Surabaya, Indonesia, laila.poltekpensby@gmail.com

\section{Fatmawati}

Politeknik Penerbangan Surabaya, Indonesia, fatmawati@poltekbangsby.ac.id

\section{Meita Maharani Sukma}

Politeknik Penerbangan Surabaya, Indonesia, mitamsukma@gmail.com

This study examines reading strategies and learning motivation on learning outcomes, analyzing key achievements and constraints in enhancing the reading experience and learning motivation, and determine Aviation English reading strategies. Quantitative and qualitative methods were both used in these survey methods to gather data from 188 respondents. The data needed for research questions contained three sections of 60 question items for quantitative research, while the qualitative method applied live interviews with eleven cadet participants. The participants completed the survey by accessing the survey through an online site on the date specified for each selected class. The sample was selected from the Aviation English language-learning classes based on the population with an online learning experience with Survey of Reading Strategies (SORS) and the English Reading Motivation Questionnaire (ERMQ). This study's output shows that the metacognitive reading strategy requires adequate knowledge in its implementation because it depends on self-regulatory competence. The results also showed that the extrinsic motivation of the cadets is more dominant than the intrinsic motivation.

Keywords: aviation polytechnic, learning motivation, learning outcomes, reading metacognitive, English lesson

\section{INTRODUCTION}

The quality of education has developed positively with the rapid development of science and technology (Darling-Hammond, 2016). This education quality further paves the way for a transition from teacher-centered to student-centered education. An essential component of student-centered education is the learning procedure, in which students use their metacognitive awareness, organize their learning procedures, and increase motivation (Mahasneh, Alkhawaldeh, \& Almakanin, 2016)(Yen et al., 2018). Learning English needs teaching patterns and aspects, namely reading, writing, speaking, and

Citation: Rochmawati, L., Fatmawati., \& Sukma, M., M. (2022). Metacognitive Reading Strategies of English Lesson at Indonesian Civil Aviation Polytechnic. International Journal of Instruction, 15(1), 583-600. https://doi.org/10.29333/iji.2022.15133a 
listening (Kriaučiūnienè \& Mažuolienè, 2017) (Gustiana, Afriazi, \& Puspita, 2019). Even though there was an increase in the score, the test results were far from expected. This is the lecturers' task to form cadets to understand the course materials. Civil Surabaya Aviation Polytechnics can make cadets as workers in reliable aviation and airports. Language acquisition is necessary, especially English, as the language of global communication and interaction. Therefore, cadets need to have high metacognition skills to achieve success. The teacher needs to see whether the learning has been appropriate and suitable for students (Fiorella \& Mayer, 2016); (Ahmadi \& Reza, 2018). The suitability of learning also requires teachers to understand students' psychological condition by convincing the lecturer and reaching students' metacognitive side (Bahri \& Corebima, 2015)(Ulu \& Ulusoy, 2019)(Hastuti, I. D., Surahmat, Sutarto, \& Dafik,2020)(Miarsyah, M., Ristanto, R. H., Lestari, P., \& Rahayu, S, 2021)(Hindun, I., Husamah, H., Nurwidodo, N., Fatmawati, D., \& Fauzi, A, 2021).

The English teacher in Surabaya Aviation Polytechnics still uses traditional language teaching methods for passing the middle and final test, such as the cadets must translate each word in the text, silent reading, and pays too much attention to grammar. Program for International Student Assessment (PISA) had taken a reading competence survey for 77 countries in 2018. On Wednesday, December 3rd, 2019, it showed that Indonesian students' reading ability rank is 74 from 77 countries. According to the survey, Indonesian students' reading comprehension is below the mean world index. As a result of the lecturers' conventional methods, many cadets felt hopeless. They still do not understand the subject of the reading texts they have read even though they have applied the methods mentioned above. The cadets perceived reading as a bored and not attractive activity. Reading English is difficult to grasp since so much attempt and spent a lot of time. As a result, nearly all the Indonesian Civil Aviation Polytechnic cadets get amateurish readers, sluggish readers, and suspended readers. Those unpleasant English reading feelings cause cadets mental impediment or evasion against English reading.

Learning success is influenced by many factors, from the teacher's side to the students'. The problems are more on students' role in learning abilities, which also pay attention to internal factors from within students and external factors outside the students. The learning process is often influenced by a person's affection for objects or activities accompanied by feelings of pleasure, attention, and active action (Oga-Baldwin, Nakata, Parker, \& Ryan, 2017)(Ness, 2016). Motivation also affects the learning success of students. Motivation is a change in a person to achieve goals, namely encouragement for students to be more active in learning. Motivation to learn is initially a natural tendency in humans. Still, it is formed in such a way, not only as a cause and mediator of learning but also as a result of learning itself (Chou, Chang, \& Lin, 2017)(Kim, 2017). Learning outcomes are the fastest evaluation after experiencing the learning process that will lead to completing learning objectives (Ahmadi \& Reza, 2018)(Chun, Kern, \& Smith, 2016).

Cadets can achieve excellence in academic performance based on their intrinsic academic motivation, which plays an essential role in learning and human life activities. Modern statistical investigations prove that students' optimal learning outcomes have intrinsic motivation and a genuine interest in their study (DePasque \& Tricomi, 2015). 
College-age students can take advantage of metacognition strategies to enhance their learning (Barenberg \& Dutke, 2019). There is a need to teach metacognitive knowledge comprehensively.

Cognitive and metacognitive strategies are the most crucial language learning strategies (Martínez \& De Zarobe, 2017)(O'Malley \& Chamot, 2012)(Božinović \& Sindik, 2017). The education system must increase the commitment to teaching students how to process information properly by utilizing cognitive and metacognitive strategies to deal with academic challenges effectively. Several studies have shown a correlation between learning outcomes and the relationship between cognitive and metacognitive strategies with motivation (Meniado, 2016)(Santisi, Magnano, Hichy, \& Ramaci, 2014)(Bahri \& Corebima, 2015)(Shang, 2016). However, there has not been much research on the main achievements and obstacles in improving the reading experience in learning English for Aviation with a qualitative approach and learning motivation analysis to determine the best reading strategies for cadets in understanding English texts. Based on these facts, the researcher examined reading strategies and learning motivation for learning outcomes. The focus is on analyzing the main achievements and constraints in improving the reading experience in English for Aviation learning, learning motivation to determine the best reading strategies that help cadets understanding English texts.

\section{METHOD}

Both quantitative and qualitative methods were applied in this survey method to collect data. The questionnaire contains three parts of the 60 question items for quantitative research. The population was Aviation Polytechnic cadets, including Diploma-3 Aeronautical Communication Officer and Diploma-3 Air Traffic Controller. One hundred eighty-eight participants were selected based on the people that have an online learning experience. They were acquired to participate by filling questionnaires through a website. The researchers collected the data from a single survey, including four individual sections. The first segment consists of demographic elements that allow participants to include basic information about themselves and their status as cadets. The second and third parts are the Survey of Reading Strategies (SORS) and the English Reading Motivation Questionnaire (ERMQ). This qualitative research explores the opinion of the participants about their reading strategies, observation, and documentation. Seven cadets as the source data were chosen in live-depth interviews and observation.

\section{FINDINGS}

\section{The Effect of Metacognitive Reading lesson Strategies and Motivation to Learn Reading}

The quantitative analysis should assess the quality and reliability of the information obtained in this study. Using the OLRS portion survey, participants answer online questions about learning experiences. Descriptive statistical analysis shows that the number of respondents in this study was 188 cadets with mean and standard deviation in Table 1. The online attitude learning component is the only aspect of the data review that involves checking the report's validity and reliability. The system results for 
analyzing the data indicated to classify the alpha of Cronbach $(\pi=0.87)$. Hence, there is high reliability in the online learning attitude segment (Table 2). The online learning attitude instrument adjusts to the validity of facing existing achievements.

Table 1

Descriptive statistical analysis

\begin{tabular}{lll}
\hline & Mean & Standard Deviation \\
\hline Reading lesson Outcomes & 82.2128 & 11.95837 \\
\hline Motivation to Learn Reading & 79.7926 & 14.40939 \\
\hline Metacognitive Reading lesson Strategies & 83.0372 & 15.29334 \\
\hline
\end{tabular}

Table 2

The correlations of variables

\begin{tabular}{|c|c|c|c|c|}
\hline & & $\begin{array}{l}\text { Reading } \\
\text { lesson } \\
\text { Outcomes }\end{array}$ & $\begin{array}{l}\text { Motivation } \\
\text { to Learn } \\
\text { Reading }\end{array}$ & $\begin{array}{l}\text { Metacognitive } \\
\text { Reading lesson } \\
\text { Strategies }\end{array}$ \\
\hline \multirow{3}{*}{$\begin{array}{l}\text { Pearson } \\
\text { Correlation }\end{array}$} & Reading lesson Outcomes & 1.000 & .749 & .727 \\
\hline & $\begin{array}{l}\text { Motivation to Learn } \\
\text { Reading }\end{array}$ & .749 & 1.000 & .868 \\
\hline & $\begin{array}{l}\text { Metacognitive Reading } \\
\text { lesson Strategies }\end{array}$ & .727 & .868 & 1.000 \\
\hline \multirow[t]{3}{*}{ Sig. (1-tailed) } & Reading lesson Outcomes & & .000 & .000 \\
\hline & $\begin{array}{l}\text { Motivation to Learn } \\
\text { Reading }\end{array}$ & .000 & . & .000 \\
\hline & $\begin{array}{l}\text { Metacognitive Reading } \\
\text { lesson Strategies }\end{array}$ & .000 & .000 & . \\
\hline \multirow[t]{3}{*}{$\mathrm{N}$} & Reading lesson Outcomes & 188 & 188 & 188 \\
\hline & $\begin{array}{l}\text { Motivation to Learn } \\
\text { Reading }\end{array}$ & 188 & 188 & 188 \\
\hline & $\begin{array}{l}\text { Metacognitive Reading } \\
\text { lesson Strategies }\end{array}$ & 188 & 188 & 188 \\
\hline
\end{tabular}

In connection with the variable Swanson's categorization, motivation to learn reading $(M=82.21, S D=11.95)$, metacognitive reading lesson strategies $(M=79.79, S D=$ $14.41)$, and reading lesson outcomes $(M=83.04, S D=15.30)$ were included into very high category (table 1). Furthermore, Pearson $r$ correlation was performed to reveal the effect of metacognitive reading lesson strategies and motivation to learn reading lesson outcomes. The results show that metacognitive reading lesson strategies had a positive and large relationship with reading lesson outcomes $(r=.749, p<.001)$. Moreover, motivation to learn reading also showed a positive and large relationship with reading lesson outcomes $(r=.727, p<.001)$ in table 2 . This statistical test result meant that the higher the student's metacognitive reading lesson strategies and motivation to learn reading, the higher the reading lesson outcomes.

Multiple regression test was carried out to investigate what independent variables contributed the most to the dependent variables. Before conducting a multiple regression test, it was necessary to carry out a classic assumption test including normality, linearity, 
homoscedasticity, and multicollinearity test. The results of the classic assumption test implied that multiple regression could be operated $(\lambda>.001, C I<30, p<.001$, F-count $=130.404)$. Besides, the scatterplots portrayed that the plots were around the straight line so that the data were normally distributed.

Table 3

The coefficients output of variable

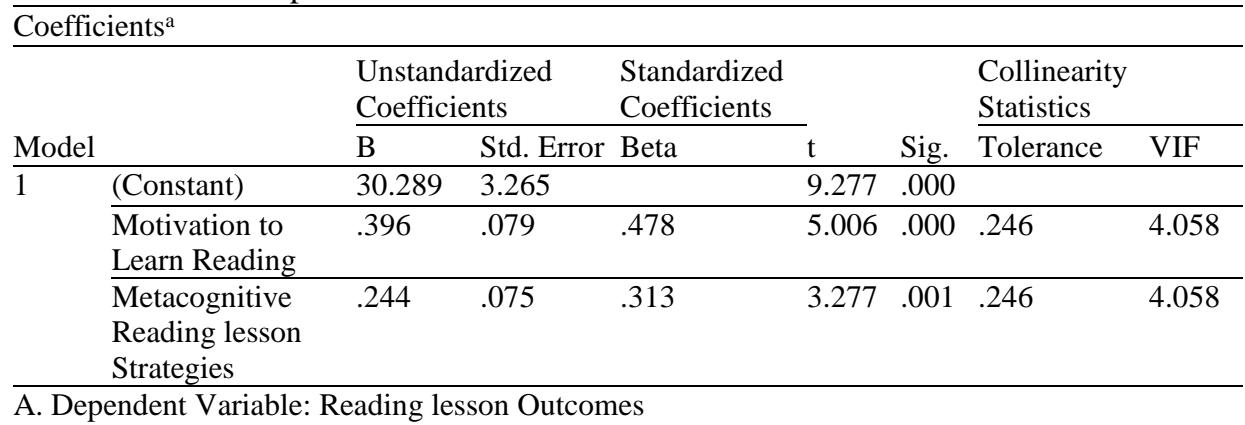

Table 3 portrays that motivation to learn reading significantly influenced reading lesson outcomes $(p<.001)$. This variable was meant to be the dominant variable that contributed the most to the value of reading lesson outcomes. Compared to the other variable, namely metacognitive reading lesson strategies, this variable had no significant influence $(p \geq .001)$.

This study generates three points. First, metacognitive reading strategy instruction brings out the cadets' attainment quantifiable escalate toward 12 weeks given metacognitive reading strategy instruction. The results showed that metacognitive reading strategy instruction influenced the skill level of cadets. In-depth interviews with 11 cadets explained how the cadets' English reading skills had built their understanding of reading in English. Besides, the observation data represented that the application of metacognitive reading strategy instruction somehow affected cadets and teacher maturity. For instance, cadet one at the first meeting felt so nervous and sluggish English reading manner, but at the end of the metacognitive reading strategy instruction week 7 , he gets vigorously.

In contrast, the English teachers who joined the study correctly combined the metacognitive reading strategy instruction into the regular classroom. Thus, the cadets become successful readers who are determined by themselves and eventually become readers who do not change. The research output strongly recommends that learning metacognitive reading strategies make cadets more selective and flexible based on the reading texts they encounter. 


\section{DISCUSSION}

\section{Achievements and Constraints to Improve Reading Experience}

Metacognitive reading instructions are a bridge for cadets to understand better how to read English texts. Cadets need knowledge or methods of how to read English texts. Teachers apply metacognitive reading learning because they believe this strategy can prepare cadets for academic needs and future jobs and careers. However, many cadets who study English for at least 8 years, starting from elementary school, are still trying to learn English or are afraid to read something in English. The national curriculum has targeted reading texts in textbooks to match the appropriate vocabulary and grammar features. These reading texts are mostly arranged in the language teaching structure and are not attractive to cadets. As a consequence, cadets are discouraged from forming healthy reading habits and interests. Many people were interested in reading what they loved, such as sports for boys and fashion and celebrities for girls (Abdullajonova, 2017).

Motivation to read in an L1 setting; emphasized that personal interest is a significant predictor of understanding and learning (Tricomi \& DePasque, 2016)(Chen \& Jang, 2010)(Vibulphol, 2016). Cadet one claimed his interest in reading has declined from middle school, as the transcript indicates and with the exception:

"I used to love reading when I was in elementary school. Elementary school teachers lead us to read lots of funny short stories with colorful pictures on each page. Back then, vocabulary was what I could handle. But now, I have to study textbooks that I am not interested in and read carefully for quizzes and exams. Besides, it is very tedious in class, taking notes, and practicing."

The cadets usually have a strong interest in learning at an early stage (Abdullajonova, 2017). Gradually, however, the monotonous teaching grammar and translation methods make them lost their appeal. Cadet 7 liked English in that case and enjoyed reading short stories in front of middle school. This situation changed when he entered middle school because of reading material or learning experiences. English teachers need to know how young people who love popular culture read what they want in everyday life. Young cadets share the same feeling of reading something relevant to their lives in response to what they want to read. Highly subject-specific learning materials contribute to increased enthusiasm and understanding (Schiefele \& Schaffner, 2016)(Stutz, Schaffner, \& Schiefele, 2016). The previous section revealed that learning to read English in Indonesia currently does not teach cadets how to read or appreciate English texts. The majority of cadets are passive students or readers whose speech and grammar skills are not entirely convincing. These readers are reliant with little trust when they are asked to read separately. Also, both language teachers and cadets have misunderstandings of English literacy. When dealing with English texts, they are faced with the problem of translating definitions rather than gaining linguistic awareness (Singer \& Alexander, 2017)(Piper, Schroeder, \& Trudell, 2016). This study's results have confirmed that the metacognitive reading lesson strategy (MRSI) has benefited cadets and teachers who participated after ten weeks. 
Nowadays, cadets cannot avoid reading comprehension vocabulary. However, reading emphasizes the vocabulary significance without being followed up on learning how to pronounce and its application, which does not help improve reading comprehension (Ouellette, 2006). The critical role of reading comprehension, practical research in enhancing EFL cadets' vocabulary knowledge has targeted both the broad dimensions and depth of vocabulary knowledge (Chung et al., 2015); (ALQAHTANI, 2015). For reading understanding ESL or EFL cadets, vocabulary awareness is essential. They should learn it in an exciting way rather than out of context (BalikcioLlu \& Efe, 2016)(Martínez \& De Zarobe, 2017)(Pascual, 2019). In this study, more than half of the respondents stated the most obvious thing in reading English texts is their lack of vocabulary, phrases, and grammar knowledge. First, this problem is how the Aviation Technology Polytechnics of Surabaya cadets learn the English language is still isolated and separate. In a way, one could look at one's vocabulary as consisting of all words with one meaning only. Usually, in learning to read English, new words are chosen before reading the text. The English teacher gives the cadets the definition of a new word straight away, and then the cadets take a pen and paper, write the word repeatedly. The teacher will only begin learning new words when the student has learned them. This technique allows first-year students to forget their new vocabulary words because they do not know what words have various uses or contexts. Cadet two, for example, commented that after the questionnaire, he said he forgot what to say. Thus, he could not read books in English comprehensively. Cadets also do not learn vocabulary in context, and there is no proper pronunciation in context. An interviewer said:

"I rarely know how to use words; English teachers rarely teach us or let us practice pronouncing words on our own. I copy a few times on paper, then gradually, I'll know what the words look like, and I'll learn how to spell them. When the English teacher tests us the vocabulary, the meaning of the words in the language, and we spell the English accordingly."

Reading aloud is the strategy most often used among cadets. The interviewee said that they can always memorize vocabulary and pass the vocabulary question without understanding how to pronounce the term or pronunciation. This style of learning vocabulary will come from Indonesian first language users. English is an alphabet system, and its primary unit consists of the pronunciation and structure of the word (spelling), and these two features also map phonological and morphological identities. On the other hand, language is a logographic system that provides little or no clue about the word's pronunciation. Therefore, for cadets of Indonesian/regional languages as their mother tongue, English vocabulary is seen or recognized as "images" or "logos." You don't know how to pronounce English words to pass the English exam. When reading English, they rely heavily on their L1 reading strategy. Readers with L1 logon scripts can use a 'visual' approach to learn the English language.

The results of in-depth interviews found that English teachers rarely expect the words spoken by their cadets. Although cadets can get high grades on exams, teachers value spelling more than pronunciation. This is also caused by necessity, namely the lack of focus on speaking testing in middle school admissions. Ironically, even though cadets 
can pronounce English terms, they also teach cadets to read aloud when there is a comprehension interruption while reading. When answering questions about the English reading techniques, cadet tree said:

"reading strategies? Umm, I don't think the technique I learned help much. They (the English teacher) told me that whenever you have difficulty reading unfamiliar words or confusing sentences, just read the sentence a few times and have the meaning. But, I tried this method, and I don't think this strategy or solution will work. I don't know how it works for the teacher but not for me."

Cadet four said, if they cannot comprehend the words because they do not have enough understanding, it will be troublesome and make cadets more irritated - struggling to sound words. L1 and L2 have gained considerable attention in the literature on reading studies. It is a consensus that knowledge of vocabulary and understanding of reading is very closely connected. Effective vocabulary learning is, therefore, important in L2 reading. Besides, for specific (ESP) readers who have minimal exposure to spoken English, a realistic understanding of vocabulary growth is more important. This means that the English teachers should send the students exciting vocabulary text and a plan to decide the meaning and common vocabulary of unknown terms (Wasik, Hindman, \& Snell, 2016; Suk, 2017). Both of these are part and package of a good understanding learning program.

The cadets spend much of their time reading and attempting to discover new terms in the dictionary. In English lessons, they learn vocabulary and the form of grammar and phrases. In certain instances, access or purpose is referred. When answering the question, for example, "how do you read? when to read in English? " The most common answer is like the statement of Cadet five:

"I will start reading by skimming the unfamiliar words in the reading text, the most important thing, and then look in the dictionary, write down the meaning, and if there are multiple meanings, I choose the first. However, I started reading it word for word."

Cadet six has the same process as defined by the previous cadets. Different people have mentioned this form of the reading process many times. Cadet five said, too:

"Apart from checking meaning first, I also analyzed the sentence structure. After searching for all unknown terms in the dictionary, I must examine the sentence structure to get context."

Cadet seven answers the question about the meaning of sentence structure analysis. He said that:

"I, hmm, for example, I break-a sentence into sections according to the part of the speech. For example, I circled all verbs, nouns, adjectives using hand gestures, underlined relative pronouns, something like that."

Reading English is taught as a process of vocabulary decoding and grammar analysis for most cadets. Two cadets have the same perception of "good English readers." They said 
that teacher told them that they have to start by memorizing the entire dictionary from A to $\mathrm{Z}$ to be very good at reading English. Another cadet confirmed that to become a successful reader of English; he tried to study the dictionary last year:

He said that the whole dictionary should be memorized for all good English readers. At that time, he was persuaded and started studying the words in the dictionary, which began with the letter "A," but I gave up in the end, and in half, I made it.

The commentaries show that reading English is all about vocabulary and grammar for many cadets of Aviation Technology Polytechnics of Surabaya. Nothing is said or known of the interpretation, organization, and presentation in English of concepts, how and where to find 'subject' phrases or recognizing 'supporting evidence,' etc. In other languages, all the above remarks indicate that cadets were not taught how to read the lecture. The conventional teaching approach focuses on vocabulary $\rightarrow$ structure or sentence analysis $\rightarrow$ translation and grammatical analysis $\rightarrow$ of specific literal comprehension questions from the earlier observations on the English teachers. They don't learn to understand or to make sense.

In comparison, the emphasis of reading English is on vocabulary and grammar rather than sense or reading (Wasik, Hindman, \& Snell, 2016)(J. Cheng \& Matthews, 2018)(Balıkc1oLlu \& Efe, 2016). Cadets prefer to use a "bottom-up" approach instead of a "top-down" approach. This trend is positively linked to the L1 tradition of literacy and its interpretation of the reading process.

Nevertheless, reading English this way just makes cadets waste more time and energy and naturally more anger and less ability to use English reading materials. It is not shocking that many respondents would find that reading English is "time-consuming," "boring," and "meaningless." Cadet 4 said:

"I don't like reading in English. I don't read it other than teacher requests or assignments. For me, it is painful and very time-consuming, especially when you spend time checking vocabulary in the dictionary. You find it with lots of definitions and no. know which one to choose, and you still don't get it even though you know every meaning of every word."

Researcher: "So, did you ask other people for help on this?"

Cadet eight: "Asking for help is useless; I know the answers. Often, when I read English, I try to articulate my problems. If someone wants to speak English well, one needs to learn more, listen more, speak more, and write more."

However, some people don't need to understand the whole text when they spend time reading; it is frustrating and choose to give up.' However, cadet 4's comments are criticized for not having read enough and memorized words, making it difficult to read English. Their reading problem lies in their lack of language knowledge and the key to achieving it (Tavakoli \& Koosha, 2016)(Edele \& Stanat, 2016). Successful comprehension is reading as much as possible. So, attentive cadets keep memorizing vocabulary and forgetting what they have learned. They continue to concentrate on 
grammar and neglect significance during reading and feel that this 'reading task' has little meaning and is fatiguing. Then it seemed like they didn't want to learn this sort of English anywhere. Reading English is a difficult task for them, and their learning has little control. They, therefore, establish psychological obstacles to reading. Or they want to give up, as if "giving up" is how their learning can be managed. Cadet nine said as follows:

"I recall vocabulary easily, or when it comes out of a sentence, sometimes I learn it, and then it is likely I don't know what it is. I don't know."

Cadet ten clarified in another case:

"Often I'm disappointed with the way I read; sometimes, I spend a lot of time looking at vocabulary. I will instead leave and hand it over to the English teacher and wait for an answer or translation. So many other subjects I look after at school."

For EFL cadets, the minimum requirement for English is 3,500 words. In other words, when reading texts, EFL cadets with more than 3500 may still have difficulty reading (Y. H. Cheng \& Good, 2009)(Huang, Chern, \& Lin, 2009). Aviation Technology Polytechnics of Surabaya cadets need to learn at least 3,500 vocabularies from primary to secondary school in this report. Therefore, learning English must be based on vocabulary and grammar in this vocabulary awareness. Focusing upon meaningless words and teaching grammar helps to read Aviation Technology Polytechnics of Surabaya cadets' understanding little because they don't see the meaning incorporated into the text. Moreover, memorizing makes cadets lazy to think objectively in different contexts; even within their ability, cadets do not deviate from the meaning of an unfamiliar term. The lecture should then teach reading strategies to make them more readable and ready to read from the text. Cadet eleven said he never read anything in English. He says:

"I rarely read anything in English. I know I have to read a lot to improve my reading comprehension of English. But I think my vocabulary knowledge is too little. I might start reading when I have some better vocabulary."

The comments show that cadets don't read much because they have limited vocabulary knowledge. However, research says cadets need to study words in various contexts anywhere from 5-16 study time to retain vocabulary. Therefore cadets need to reading extensively to gain language access to develop their vocabulary rather than learning a meaningless language from the context. And one powerful way to inspire them to read thoroughly is to teach them reading strategies to get them comfortable with reading materials in English. Moreover, cadets understand that English reading is not merely a structure to decipher or evaluate grammar. Reading is learning not only the comprehension of words but the interpretation of texts (Kriaučiūnienè \& Mažuolienè, 2017)(Lee \& Yoon, 2017). Reading is an essential source of speech knowledge for cadets and a successful means of studying other languages and cultures. It is more critical to read techniques than vocabulary and grammar or translation to prevent fossilization in the early phases of language learning (Alqahtani, 2015)(Y. H. Cheng \& Good, 2009)(J. Cheng \& Matthews, 2018). 


\section{The Implication of Motivation to Learn Reading and Reading lesson Strategies for Cadets}

Several studies have suggested the application of metacognitive reading lesson strategies in improving the students' reading skills, such as (Bahri \& Corebima, 2015)(Cosentino, 2017)(Lipari, 2016)(Mahasneh et al., 2016). Several empirical studies were performed in the L2 context to analyze the impact on reading motivation in the EFL context of metacognitive reading lesson strategies (Badrkoohi \& Maftoon, 2017) (Chung, Chen, \& Kuo, 2015)(Meniado, 2016)(Martínez \& De Zarobe, 2017). The metacognitive reading should make cadets more motivated and confident in reading English. The metacognitive reading lesson strategy requires them to understand the reading task by questioning and fully summarizing. Thus, the results of learning to read are higher than before. Metacognitive Reading Strategy Instruction (MRSI) (Febijanto, 2016) affects reading lesson outcomes. Earlier studies showed that metacognitive reading strategies are better for students with lower levels of English (Tavakoli \& Koosha, 2016) (Sukmawati, 2019)(Yen et al., 2018) (BalıkcioLlu \& Efe, 2016)(Kutluturk \& Yumru, 2017). MRSI supports all cadets at different linguistic skill levels, regardless of their varying levels of language ability. Cadets of all ability levels benefit from this education instead of their traditional English lesson and teaching environment. They should explore different read strategies, determine the efficacy of reading strategies, and eventually choose practical resources based on their learning. Thus, English language skills and reading lesson outcomes experienced almost the same reading comprehension improvements, awareness of reading strategies, and motivation to read.

This study also showed that the number of cadets who had extrinsic motivation was more than those who had intrinsic motivation. This is an important finding because intrinsic motivation is related to attention, depth in processing, and learning. Meanwhile, increasing motivation can be done by giving awards (Cosentino, 2017) (Tricomi \& DePasque, 2016) (Vibulphol, 2016). Two processes that influence intrinsic motivation are (1) the perception of the locus of causality and (2) the change in feelings of competence and self-determination. Thus, individuals will evaluate their activities based on whether their performance will increase or decrease their feelings of self-worth, competence or determine their destiny. Expectancy factors and locus of causality felt by an individual greatly influence intrinsic motivation (Schiefele, 2017). Students who have intrinsic motivation will carry out learning activities voluntarily or with awareness and actions to face the challenges of fulfilling competencies by using their creative abilities (Soemer \& Schiefele, 2018)(Badrkoohi \& Maftoon, 2017). Intrinsic motivation has a strong association with academics, self-confidence, and cognitive engagement, whereas extrinsic motivation has a low association. Students who have intrinsic motivation will learn for satisfaction, while students with extrinsic motivation will learn based on external rewards (Bahri \& Corebima, 2015). Extrinsic motivation has a positive relationship with self-orientation toward perfection (Lin, Zhang, \& Zheng, 2017). Intrinsic and extrinsic motivation have their advantages so that in the acquisition of learning outcomes, there is no significant difference. Students with intrinsic motivation and extrinsic motivation in acquiring reading lesson outcomes in English did not significantly differ. 
Metacognitive reading strategies include: how to start reading, difficulty in reading English and copying strategies, strategies to remember the gist, monitoring strategies, strategies to stay focused on reading, and tracking and understanding the primary material. Start reading by reading word for word; set the purpose of reading why you should read; view titles and images; memorize key points and some vocabulary; read phrase by phrase to get the main idea; use the instructor's pedagogical instructions to read (Castles, Rastle, \& Nation, 2018). They first noted that they started by identifying the word with the highest frequency score. Second, some participants stated that they set reading goals and asked themselves why they were reading. Third, other participants said they read the title first and then saw the meaning-making process's visuals. Fourth, some cadets noted that they memorized some critical information. Some others mentioned that they moved to the next level by reading phrase by phrase to get the main idea in fifth place. Likewise, some of them indicated that the instructor's instruction on reading strategies helped them start reading effectively in sixth place. Besides, participants in the control group also mentioned several ways they started reading. They recorded the time when reading started, which got the highest frequency score. Both participants stated that they translated the title text. However, other participants said that they read the topic sentence first and then filled in the text. The three other participants reported that they found the meaning of new words in the dictionary. Fourth, some of them said that they began to read silently. Reading English and copying reading strategies many times in the first year to get to the point is difficult because reading is very challenging. Translating into L1 is also tricky because of its complexity and identifying formal and informal English expressions. Understanding abbreviations and memorizing is difficult for them. Applying different reading strategies in the final exam; reading English books and newspapers to enhance extensive reading; academic words to understand the literary text designed for the TOEIC test is challenging studying academic vocabulary.

Different metacognitive strategies implementation while reading is crucial. The participants noted several difficulties they encountered while reading the text. Several challenges are getting reading comprehension, identifying formal and informal English, understanding abbreviations, applying reading strategies, reading extensively, learning academic words (Kriaučiūnienè \& Mažuolienè, 2017)(Lipari, 2016). Methods for Memorizing Key Sections include taking short notes, repetition, monitoring, and evaluation, using reading techniques, asking questions after reading, identifying grammar, highlighting essential points, writing knowledge-monitoring. The participants mention several monitoring strategies in reading. They include observing fluency, the second asking questions and responding to them, the third checking reading comprehension by pausing, and the fourth discussing main ideas. Strategies for Staying Focused on Reading involve interpretation. Cadets notes effectively staying focused while reading using several reading strategies to rereading the passage as the two highest frequencies. The three of them began reading critically in a quiet place, the fourth relaxed, the fifth stopped in time, and the sixth broke away from their personal and professional lives. Cadets use several strategies to track and understand the main points. Methods include underlining important information, taking notes on important 
information, summarizing main points, focusing on terminology, skimming, and imagining the story. First, they highlight important issues, and second, note that they have received high-frequency scores in a row. However, skimming and making pictures in mind has gotten successively lower frequencies.

\section{CONCLUSION}

This study indicates that cadets are using metacognitive strategies in reading lessons require intricate knowledge in their implementation. The successful use of metacognitive strategies is highly dependent on the ability to self-regulate. The cadets' motivation does not affect reading lesson outcomes motivation than cadets have intrinsic motivation. The reading result of cadets with extrinsic motivation and intrinsic motivation is not a significant difference. Implementing metacognitive strategies in reading foreign languages takes time to develop metacognitive awareness. Each cadet has a different motivation in the learning process. The results show that if the cadets have the most extrinsic motivation compared to intrinsic motivation, it is necessary to develop intrinsic motivation from the cadets, which will affect the learning process. Increasing intrinsic motivation can be achieved by applying various learning methods. Therefore the researchers recommend further research related to the development of intrinsic motivation.

This study shows that cadets who use metacognitive strategies in reading lessons require complicated knowledge. The successful use of metacognitive strategies is highly dependent on the ability to self-regulate. The motivation of cadets does not affect the acquisition of motivation to learn to read when compared to intrinsic motivation. The comparative results of cadets' readings with extrinsic and intrinsic motivation did not show a significant difference. Learning metacognitive reading strategies has proven to be very useful for an Aviation English teacher to help cadets be more independent and empowering for students. Cadets are better prepared to make judgments about their efforts to improve their English reading terminology through instruction in metacognitive reading strategies. Reader's strategy depends not only on age, personality, chosen learning style, or reading goals but also on individual learning styles, preferences, or learners' resistance.

The results showed that cadets of cadets enjoyed the atmosphere of learning metacognitive reading strategies. The simple cluster session in the teaching gives the cadets a contrasting perspective through their peers who are the same age when they read in groups. This setting makes them challenge each other and reinforce ideas mutually. Each cadet has different motivations in the learning process. The results showed that if cadets have greater extrinsic motivation than intrinsic motivation, it is necessary to develop the acquisition of intrinsic motivation from cadets, which will affect the learning process. Obtaining intrinsic motivation can be done by applying various learning methods. Therefore, further research is needed related to the development of intrinsic motivation. This research is limited to the scope of the Surabaya Aviation Polytechnic with aviation English class cadets. Therefore, the research results may not be generalizable to be applied worldwide. Therefore, further research will require in-depth qualitative study to explore better insights into the age, 
personality, learning style or selected reading goals, individual learning styles, preferences, or learners' resistance.

\section{REFERENCE}

Abdullajonova, N. N. (2017). Modern educational technology. European Journal of Technical and Natural Sciences. 17(2), 44-47. https://doi.org/10.20534/ejtns-17-2-4447

Ahmadi, D., \& Reza, M. (2018). The use of technology in English language learning: A literature review. International Journal of Research in English Education, 3(2), 115125 .

Alqahtani, M. (2015). The importance of vocabulary in language learning and how to be taught. International Journal of Teaching and Education. https://doi.org/10.20472/te.2015.3.3.002

Badrkoohi, A., \& Maftoon, P. (2017). Individual differences and 12 motivation: The case of EFL Learners. International Journal of Applied Linguistics and English Literature. https://doi.org/10.7575/aiac.ijalel.v.6n.3p.199

Bahri, A., \& Corebima, A. D. (2015). The contribution of learning motivation and metacognitive skill on cognitive learning outcome of students within different learning strategies. Journal of Baltic Science Education.

Balıkcıglu, G., \& Efe, T. (2016). The role of metacognitive activities on university level preparatory class EFL learners $\square$ Reading comprehension. Procedia - Social and Behavioral Sciences. https://doi.org/10.1016/j.sbspro.2016.10.024

Barenberg, J., \& Dutke, S. (2019). Testing and metacognition: retrieval practise effects on metacognitive monitoring in learning from text. Memory. https://doi.org/10.1080/09658211.2018.1506481

Božinović, N., \& Sindik, J. (2017). Construction of the questionnaire on foreign language learning strategies in specific croatian context. Collegium Antropologicum.

Castles, A., Rastle, K., \& Nation, K. (2018). Ending the reading wars: Reading acquisition from novice to expert. Psychological Science in the Public Interest, 19(1), $5-51$.

Chen, K.-C., \& Jang, S.-J. (2010). Motivation in online learning: Testing a model of self-determination theory. Computers in Human Behavior, 26(4), 741-752. https://doi.org/10.1016/j.chb.2010.01.011

Cheng, J., \& Matthews, J. (2018). The relationship between three measures of L2 vocabulary knowledge and L2 listening and reading. Language Testing. https://doi.org/10.1177/0265532216676851

Cheng, Y. H., \& Good, R. L. (2009). LI glosses: Effects on EFL learners' reading comprehension and vocabulary retention. Reading in a Foreign Language. 
Chou, P. N., Chang, C. C., \& Lin, C. H. (2017). BYOD or not: A comparison of two assessment strategies for student learning. Computers in Human Behavior, 74, 63-71.

Chun, D., Kern, R., \& Smith, B. (2016). Technology in language use, language teaching, and language learning. The Modern Language Journal, 100(S1), 64-80.

Chung, H.-H., Chen, S.-C., \& Kuo, M.-H. (2015). A study of EFL college students' acceptance of mobile learning. Procedia - Social and Behavioral Sciences. https://doi.org/10.1016/j.sbspro.2015.01.479

Cosentino, C. L. (2017). The effects of self-regulation strategies on reading comprehension, motivation for learning, and self-efficacy with struggling readers. ProQuest Dissertations and Theses.

Darling-Hammond, L. (2016). Research on teaching and teacher education and its influences on policy and practice. Educational Researcher. https://doi.org/10.3102/0013189X16639597

DePasque, S., \& Tricomi, E. (2015). Effects of intrinsic motivation on feedback processing during learning. NeuroImage. https://doi.org/10.1016/j.neuroimage.2015.06.046

Edele, A., \& Stanat, P. (2016). The role of first-language listening comprehension in second-language reading comprehension. Journal of Educational Psychology, 108(2), 163.

Febijanto, I. (2016). Pembangunan pltmh ranteballa di kabupaten luwuk, sulawesi selatan sebagai proyek pengurangan emisi rumah kaca. Jurnal Teknologi Lingkungan, 11(1), 39. https://doi.org/10.29122/jtl.v11i1.1221

Fiorella, L., \& Mayer, R. E. (2016). Eight ways to promote generative learning. Educational Psychology Review, 28(4), 717-741.

Gustiana, P. A., Afriazi, R., \& Puspita, H. P. (2019). The comparative study between reading strategies used by successful and unsuccessful students. Journal of English Education and Teaching. https://doi.org/10.33369/jeet.2.4.15-31

Hastuti, I. D., Surahmat, Sutarto, \& Dafik. (2020). The Effect of Guided Inquiry Learning in Improving Metacognitive Skill of Elementary School Students. International Journal of Instruction, 13(4), 315-330. https://doi.org/10.29333/iji.2020.13420a

Hindun, I., Husamah, H., Nurwidodo, N., Fatmawati, D., \& Fauzi, A. (2021). ELearning in COVID-19 pandemic: Does it challenge teachers' work cognition and metacognitive awareness? International Journal of Instruction, 14(3), 547-566. https://doi.org/10.29333/iji.2021.14332a

Huang, H. chou, Chern, C. lan, \& Lin, C. cheng. (2009). EFL learners' use of online reading strategies and comprehension of texts: An exploratory study. Computers and Education. https://doi.org/10.1016/j.compedu.2008.06.003

Kim, Y. S. G. (2017). Why the simple view of reading is not simplistic: Unpacking 
component skills of reading using a direct and indirect effect model of reading (DIER. Scientific Studies of Reading, 21(4), 310-333.

Kriaučiūnienė, R., \& Mažuolienè, Z. (2017). Developing reading skills of the new generation students. Studies About Languages. https://doi.org/10.5755/j01.sal.0.30.16673

Kutluturk, S., \& Yumru, H. (2017). Cognitive and Metacognitive Strategy Training to Enhance Freshmen's Reading Skills. International Journal of Language and Literature.

Lee, J., \& Yoon, S. Y. (2017). The effects of repeated reading on reading fluency for students with reading disabilities: A meta-analysis. Journal of Learning Disabilities, 50(2), 213-224.

Lin, C. H., Zhang, Y., \& Zheng, B. (2017). The roles of learning strategies and motivation in online language learning: A structural equation modeling analysis. Computers and Education. https://doi.org/10.1016/j.compedu.2017.05.014

Lipari, G. E. (2016). Reading comprehension intervention: Metacognitive strategy instruction with sixth grade students. Dissertation Abstracts International Section A: Humanities and Social Sciences.

Mahasneh, A., Alkhawaldeh, M., \& Almakanin, H. (2016). Assessing students' metacognitive awareness reading strategies in Jordan. North American Journal of Psychology.

Martínez, A. G., \& De Zarobe, Y. R. (2017). Comparing the benefits of ametacognitive reading strategy instruction programme between clil and efl primary school students. Elia. https://doi.org/10.12795/elia.2017.i17.04

Meniado, J. C. (2016). Metacognitive reading strategies, motivation, and reading comprehension performance of Saudi EFL students. English Language Teaching. https://doi.org/10.5539/elt.v9n3p117

Miarsyah, M., Ristanto, R. H., Lestari, P., \& Rahayu, S. (2021). Metacognitive on pteridophyte: A unification of cooperative integrated reading and composition and guided inquiry (CirGI). International Journal of Instruction, 14(3), 481-500. https://doi.org/10.29333/iji.2021.14328a

Ness, M. K. (2016). Reading comprehension strategies in secondary content area classrooms: Teacher use of and attitudes towards reading comprehension instruction. Reading Horizons: A Journal of Literacy and Language Arts, 49(2), 5.

O'Malley, J. M., \& Chamot, A. U. (2012). A cognitive theory of learning. In Learning Strategies in Second Language Acquisition. https://doi.org/10.1017/cbo9781139524490.004

Oga-Baldwin, W. Q., Nakata, Y., Parker, P., \& Ryan, R. M. (2017). Motivating young language learners: A longitudinal model of self-determined motivation in elementary school foreign language classes. Contemporary Educational Psychology, 49, 140-150. 
Ouellette, G. P. (2006). What's meaning got to do with it: The role of vocabulary in word reading and reading comprehension. Journal of Educational Psychology. https://doi.org/10.1037/0022-0663.98.3.554

Pascual, G. R. (2019). Metacognitive awareness of reading strategies of the prospective ESL teachers. Asian EFL Journal.

Piper, B., Schroeder, L., \& Trudell, B. (2016). Oral reading fluency and comprehension in Kenya: Reading acquisition in a multilingual environment. Journal of Research in Reading, 39(2), 133-152.

Santisi, G., Magnano, P., Hichy, Z., \& Ramaci, T. (2014). Metacognitive strategies and work motivation in teachers: An empirical study. Procedia - Social and Behavioral Sciences. https://doi.org/10.1016/j.sbspro.2014.01.373

Schiefele, U. (2017). Classroom management and mastery-oriented instruction as mediators of the effects of teacher motivation on student motivation. Teaching and Teacher Education. https://doi.org/10.1016/j.tate.2017.02.004

Schiefele, U., \& Schaffner, E. (2016). Factorial and construct validity of a new instrument for the assessment of reading motivation. Reading Research Quarterly. https://doi.org/10.1002/rrq.134

Shang, H. F. (2016). Online metacognitive strategies, hypermedia annotations, and motivation on hypertext comprehension. Educational Technology and Society.

Singer, L. M., \& Alexander, P. A. (2017). Reading across mediums: Effects of reading digital and print texts on comprehension and calibration. The Journal of Experimental Education, 85(1), 155-172.

Soemer, A., \& Schiefele, U. (2018). Reading amount as a mediator between intrinsic reading motivation and reading comprehension in the early elementary grades. Learning and Individual Differences. https://doi.org/10.1016/j.lindif.2018.06.006

Stutz, F., Schaffner, E., \& Schiefele, U. (2016). Relations among reading motivation, reading amount, and reading comprehension in the early elementary grades. Learning and Individual Differences. https://doi.org/10.1016/j.lindif.2015.11.022

Sukmawati, F. S. (2019). Metacognitive strategy for enhancing the grade XI students' reading comprehension. Tadris Bahasa Ingriss Journal.

Tavakoli, H., \& Koosha, M. (2016). The effect of explicit metacognitive strategy instruction on reading comprehension and self-efficacy beliefs: The case of Iranian University EFL students. Porta Linguarum.

Tricomi, E., \& DePasque, S. (2016). The role of feedback in learning and motivation. Advances in Motivation and Achievement. https://doi.org/10.1108/S0749742320160000019015

Ulu, H., \& Ulusoy, M. (2019). The development of metacognitive awareness of reading strategies through WebQuest based teaching. Pegem Egitim ve Ogretim Dergisi. 
https://doi.org/10.14527/pegegog.2019.025

Vibulphol, J. (2016). Students' motivation and learning and teachers' motivational strategies in english classrooms in Thailand. English Language Teaching, 9(4), 64-75.

Wasik, B. A., Hindman, A. H., \& Snell, E. K. (2016). Book reading and vocabulary development: A systematic review. Early Childhood Research Quarterly, 37, 39-57.

Yen, M. H., Wang, C. Y., Chang, W. H., Chen, S., Hsu, Y. S., \& Liu, T. C. (2018). Assessing metacognitive components in self-regulated reading of science texts in ebased environments. International Journal of Science and Mathematics Education. https://doi.org/10.1007/s10763-017-9818-2 